\title{
ジゴキシンの薬物速度論的パラメータの臨床的測定法とその血中濃度予測性*1
}

新岡正法, 七戸孝光, 荒川昌子, ${ }^{* 2}$ 福田良平, ${ }^{* 3}$ 斉藤晶子, 大和田栄治, 伊藤圭二 ${ }^{* 4}$ 市立小樽病院薬局, $* 2$ 同内科, $* 3$ 北海道薬科大学 $* 4$

\section{A Method for Estimating Digoxin Pharmacokinetic Parameters and Its Predictability for the Serum Concentration*1}

\author{
MASANORI NIOKA, TAKAMITSU SHICHINOHE, MASAKO ARAKAWA, *2 \\ RYOHEI FUKUdA, ${ }^{* 3}$ AKIKo SAITo, EIjI OWADA, and KeIJI ITO*4
}

Department of Pharmacy,*2 and Internal Medicine, *3 Otaru Municipal Hospital Hokkaido Institute of Pharmaceutical Sciences*4

(Received July 18, 1983)

To estimate pharmacokinetic parameters for individualized digoxin therapy, a method which is available to clinical practice was studied in 2 healthy volunteers and 4 patients with heart disease.

At the beginning of a once-daily regimen, the prescribed dose was administered and 9 blood samples were drawn in 48 hours without receiving the dose on Day 2, if possible. On Day 3 , a routine digoxin therapy was started and to estimate parameters more accurately, several additional blood samples were drawn just before the next dose of digoxin for measuring the minimum digoxin concentrations (SGC) and 2 hours after the digoxin ingestion for maximum SGC.

The ability to predict SGC of this method based on repetitive dosing data was evaluated by comparing observed and predicted SGC. There was statistically significant correlation between observed and predicted SGC, where the prediction error was $11.9 \pm 9.4$ (mean $\%$ S.D., $n=20)$. The method based on repetitive dosing data can be used in clinical practice, because fairly accurate parameters can be obtained by this method without interrupting a routine digoxin therapy.

Keywords_-digoxin; heart disease; dosage regimen; serum concentration prediction; repetitive dosing

ジゴキシンは治療域が狭く，その体内動態にも大きな 個体差が認められることから，有効かつ安全なジゴキシ ン療法を行らには患者個々に対する投与計画を立てるこ とが必要である.1 3) そのためにこれまでも数多くのノ モグラムや数式が考案されているが，その血中濃度予測 性は必ずしも十分とはいい難い.4) このような場合は血 中濃度を測定し薬物速度論的手法を用いて投与計画を立 てることが望ましいとされている、しかしながら，ジゴ キシンは2-コンパートメントモデルでその体内動態が示

*1 本報の一部は日本薬学会第 103 年会（東京, 1983 年 4 月）で発表.

*2,3 小梅市若松 1 丁目 2-1；2-1, Wakamatsu 1chome, Otaru, 047 Japan

*4 小梅市桂岡町 7-1；7-1, Katsuraoka-cho, Otaru, 047-02 Japan
され, しかも半減期が約40時間と長いことから, 十分満 足しらる速度論的パラメータを得るためには長時間かつ 多数回の採血が必要となる. したがって，これを実際臨 休面に適用することは，決して容易ではない。

今回, 著者らはジゴキシンの薬物速度論的投与計画立 案に際し, 臨床的に実行可能と思われる採血プロトュー ルを作成し，これを健常人および入院患者に適用し検討 を加えたので報告する。

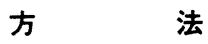

\section{1. 対 象}

健康な成人男子志願者 2 名，および心疾患のため入院 している成人男子患者 3 名と成人女子患者 1 名を対象と した.

なお，被験者にはあらかじめジゴキシン血中濃度測定 
の目的就よび方法について説明し承諾を得た．

\section{2. 投与方法および投与棛形}

ジゴキシンは 1 錠中 $0.25 \mathrm{mg}$ を含有する錠剂（ジゴキシ ン錠; 中外）を $0.5 \sim 2$ 錠, 適宜経口投与した.

\section{3. 血中瀿度測定}

採取した血液から分離した血清試料は直らに凍結保存 し, 各被験者ごとに一括してそのジゴキシン濃度を測定 した. 血清ジゴキシン濃度の定量汇は125I-ラジオイムノ アッセイキット（DIGOXIN RIABEAD, ABBOTT社） を用い,5) 測定はすべて二重測定で行った.

\section{4. 血中瀿度データの解析}

モデルとして2-コンパートメントモデルを用いた以 外, 西花らの方法6) に準じて行った.

\section{結果および考察}

\section{1. 健常人における検討}

1）単回投与時の血中濃度

ジゴキシン投与計画の臨床応用を試みるため, まず 2 名の健常人について検討を加えた。この場合, 早朝空腹 時にジゴキシン $0.5 \mathrm{mg}$ を経口投与し，24時間にわたり血 中濃度を測定した. Fig. 1 亿血中濃度推移を, またこれ から得られたパラメータを Table 1 に示す.

その結果, パラメータには 2 名の間で大きな差が認め られ，臨床上，治療の個別化の重要性が示唆された。

2) 繰り返し投与時の血中濃度

単回投与で得られた上記パラメータを用いて, 繰り返 乙投与時の血中濃度の予測を行った。すなわち, 健常人 $\mathrm{A}$ 拈よびBにそれぞれ0.125拉よび0.25mgのジゴキシン を, 早朝空腹時, 5 日間連続投与し, その間に得られた 血中濃度実測値を前述のパラメータに基づくシミュレー ション值と比較した. その結果 Fig. 2 にみられるよう に, これらは必ずしも一致せず，特にB の場合において 違いが著しかった.

そこで，これら繰り返し投与時の実測值を用い，

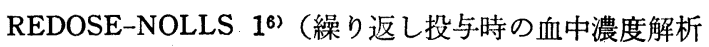
プログラム) によるカーブフィッティングを行ったとこ ろ，Fig. 3 に示す曲線が得られた。このとき算出された パラメータは, Table 2 亿示すように, $\beta$ および $\mathrm{V}_{\beta}$ に 拈いて単回投与に基づくそれ（Table 1) とは大きく異な る值を与觉た。

Tsujimoto ら4) によれば，同一個体でもクレアチニン クリアランスで $8.4 \%$, 血中ジゴキシン濃度で $12: 5 \%$ の 日間変動が認められるとされている。このことは, 健常 人飞対する上述の結果からも明らかなように，1回の投 与のみからパラメータを算出し，これにようて繰り返し

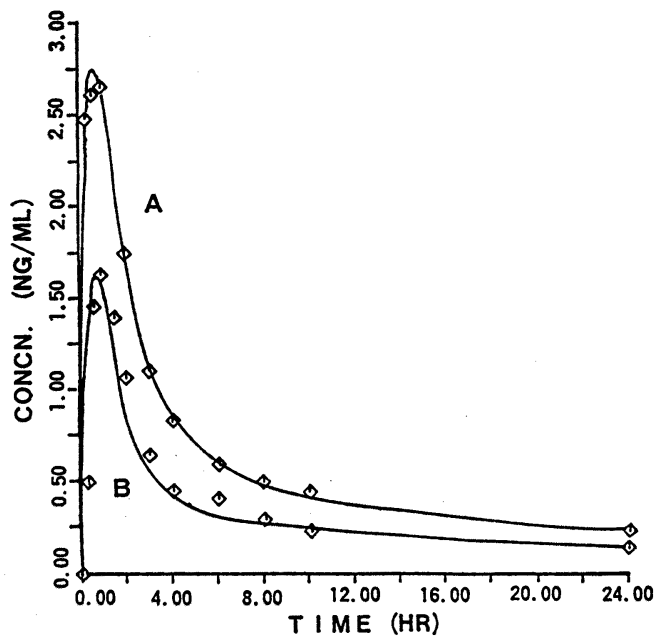

Fig. 1. Serum Digoxin Concentrations for Two Healthy Volunteers (A and B) Received $0.5 \mathrm{mg}$ Digoxin Orally

Table 1. Pharmacokinetic Parameters Based on Single-Dose Data

\begin{tabular}{ccccc}
\hline \hline Subject & $\begin{array}{c}k_{a} \\
\left(h^{-1}\right)\end{array}$ & $\begin{array}{c}\alpha \\
\left(h^{-1}\right)\end{array}$ & $\begin{array}{c}\beta \\
\left(h^{-1}\right)\end{array}$ & $\begin{array}{c}\left.v_{\beta}^{a}\right) \\
(1)\end{array}$ \\
\hline A & 3.73 & 0.589 & 0.0355 & 643 \\
B & 2.04 & 1.118 & 0.0588 & 577 \\
\hline
\end{tabular}

a) Assuming that fraction of dose absorbed equals 1 .

投与時の血中濃度を予測することが妥当でないことを示 唆するものである.したがって，より適切なパラメータ をらるためには，投与ごとの吸収あるいは消失にかかわ る変動を平均化する意味で, 繰り返し投与時のデータを ある程度補足することが必要と考えられる．この場合， 1 回目投与における採血点は可能な限り少なくするよう 考虑されなければならない。

3）臨床的採血プロトコール

以上述べた点を考虑し, 臨床的に実行可能な採血プロ トコールの作成を試みた。Fig. 4 は 1 日 1 回24時間ごと に服薬する場合の 1 例である.すなわち，プロトコール 最初の投与後, 治療に支障のない限り 2 回目を休薬し,

48時間まで $0,1,2,3,4,8,12,24$ および48時間に血中濃 度を測定する.こうして可能な限り $\boldsymbol{\beta}$ 相に関する多くの データを得るようにする。 その後 1 日 1 回投与を続け, 最低血中濃度を与学る投与直前および最高血中濃度付近 と考兄られる投与後 2 時間に和ける血中濃度を数回測定 
A

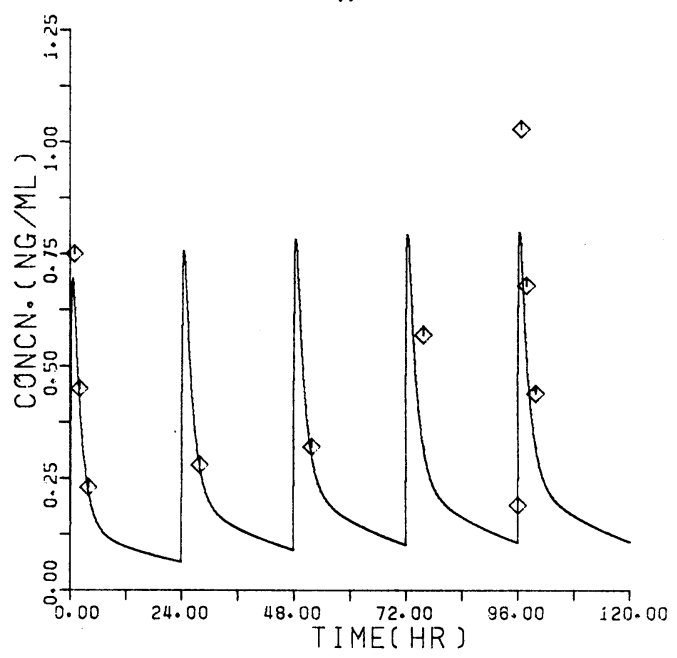

B

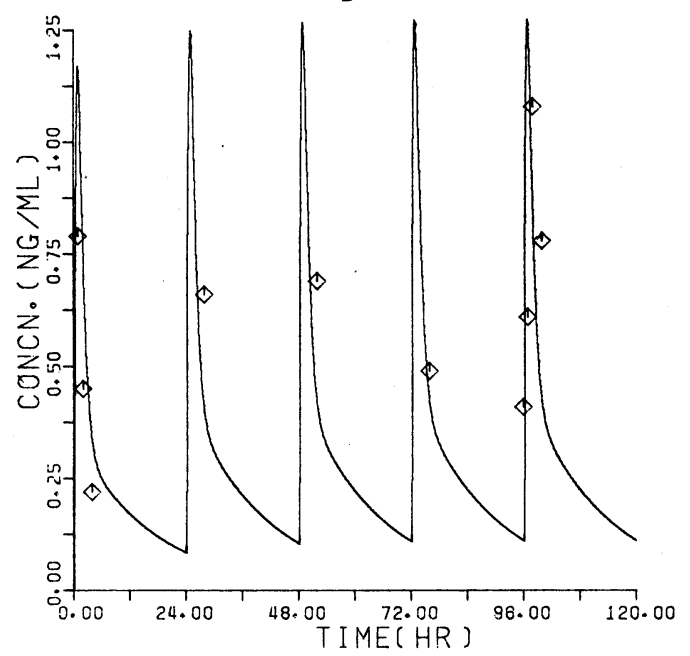

Fig. 2. Observed and Predicted Serum Digoxin Concentrations Based on Single-Dose Data in Two Healthy Volunteers (A and B)

$\diamond$ : Observed concentrations

- Predicted concentration curves based on the parameters in Table 1.
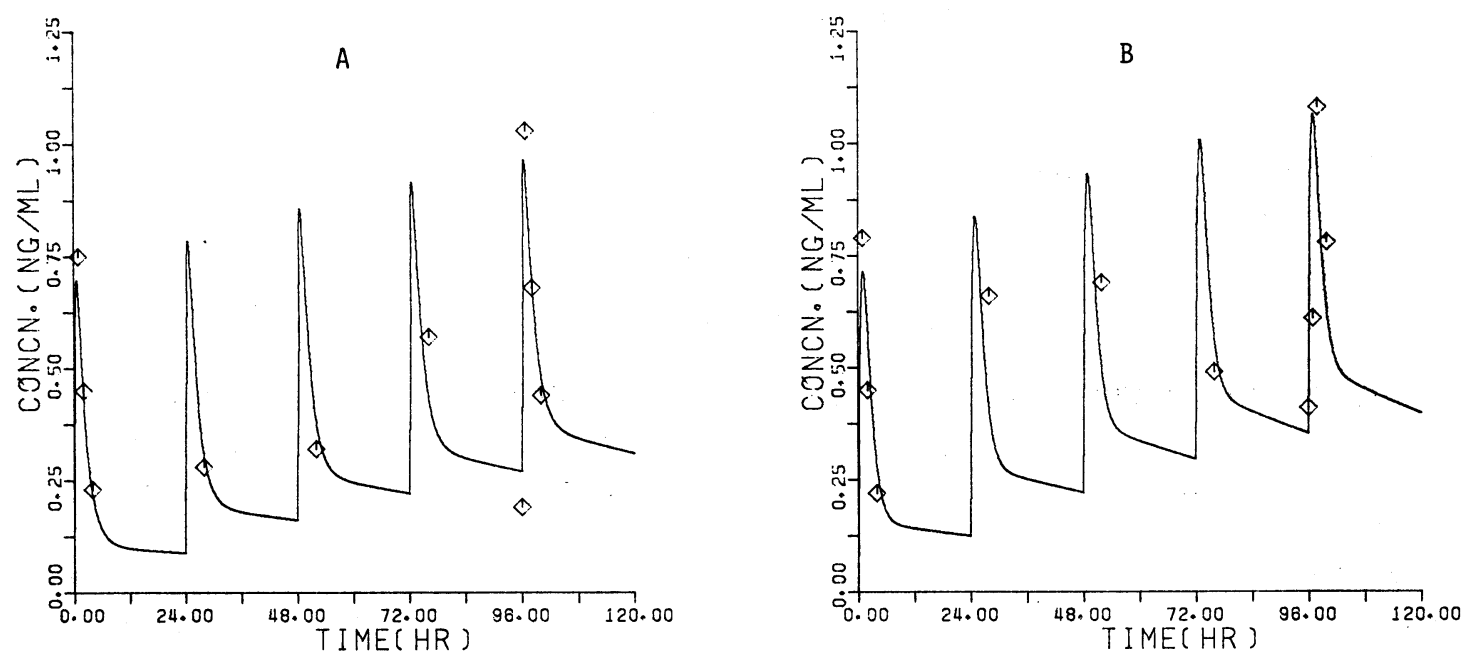

Fig. 3. Curve Fit to Serum Digoxin Concentrations after Repetitive Oral Dosing in Healthy Volunteers (A and B)

$\diamond$ : Observed concentrations

— : Nonlinear least-squares regression curves for observed data 
Table 2. Pharmacokinetic Parameters Based on Repetitive Dosing Data

\begin{tabular}{ccccc}
\hline Subject & $\begin{array}{c}k_{a} \\
\left(h^{-1}\right)\end{array}$ & $\begin{array}{c}\alpha \\
\left(h^{-1}\right)\end{array}$ & $\begin{array}{c}\beta \\
\left(h^{-1}\right)\end{array}$ & $\begin{array}{c}\left.V_{\beta}^{a}\right) \\
(1)\end{array}$ \\
\hline A & 3.74 & 0.539 & 0.00817 & 1043 \\
B & 1.10 & 0.878 & 0.0106 & 1414 \\
\hline
\end{tabular}

a) Assuming that fraction of dose absorbed equals 1.

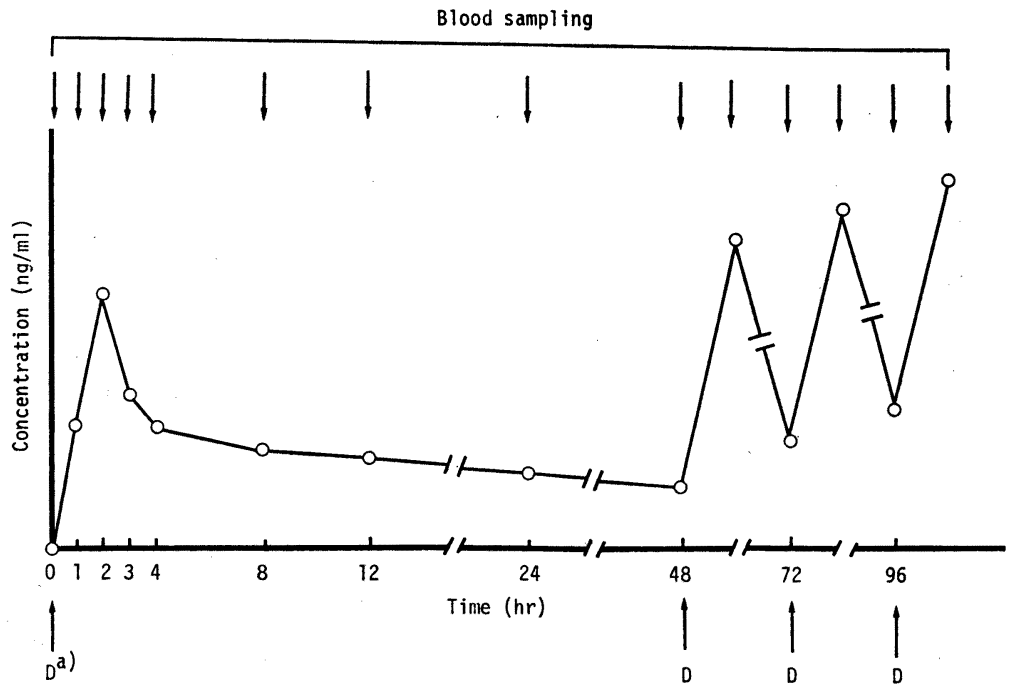

Fig. 4. Protocol for Estimating Pharmacokinetic Parameters

a) Daily dose of digoxin

し、これらを先のデータに追加し，パラメータを算出す

る.

\section{2. 患者における検討}

以上述べたプロトコールを 4 名の患者に適用し検討し た結果を Fig. 5〜8に, また患者のプロフィールと得ら れたパラメータを Table 3 に示す。

1) 症例-1 (Fig. 5, 患者C)

80歳の右胸心の女性患者で, 1 日0.25mgのジゴキシン 治療開始時に， 0 ７2時間までの测定值を用いてパラメ 一タを算出した (Table 3). こうして得られたパラメー タによるシミュレーション結果はモニタリング值（初回 投与後 336 及び 338 時間）とよく一致した.

2) 症例- 2 (Fig. 6, 患者D)

36歳のうっ血性心不全の男性で, 入院時すでに 1 日 $0.25 \mathrm{mg}$ のジゴキシンを服薬していたため， 2 日間休薬し てから投与を再開した。 このとき初期濃度 (Fig. 6 亿お
けるゼロ時間値）として $0.2 \mathrm{ng} / \mathrm{ml}$ 程度が認められた が, 本法によるデータ解析では初期濃度がゼロでなくて も解析可能なので，2回目投与までの実測值をそのまま 用いパラメータを算出した (Table 3). このパラメータ を用いシミュレーションを行ったところ, 定常状態に拈 けるモニタリング値との比較において，ほぼ满足すべき 結果を与えた。

3) 症例-3 (Fig. 7, 患者 $\mathrm{E}$ )

36歳のうっ血性心不全の男性で, 1 日0.25mgのジゴキ シン治療開始時にパラメータ決定のための血中濃度測定 を行った. しかしながら，治療上の理由から Fig. 4 の プロトコールを実施することができず， $\boldsymbol{\beta}$ 相に関するデ 一タが不十分であったため, さらに 4〜6回目の繰り返 し投与時のデータをも加えてフィッティングし，パラメ 一タの算出を行った (Table 3). このパラメータを用い てシミュレーションを行ったところ, 定常状態でのモニ 


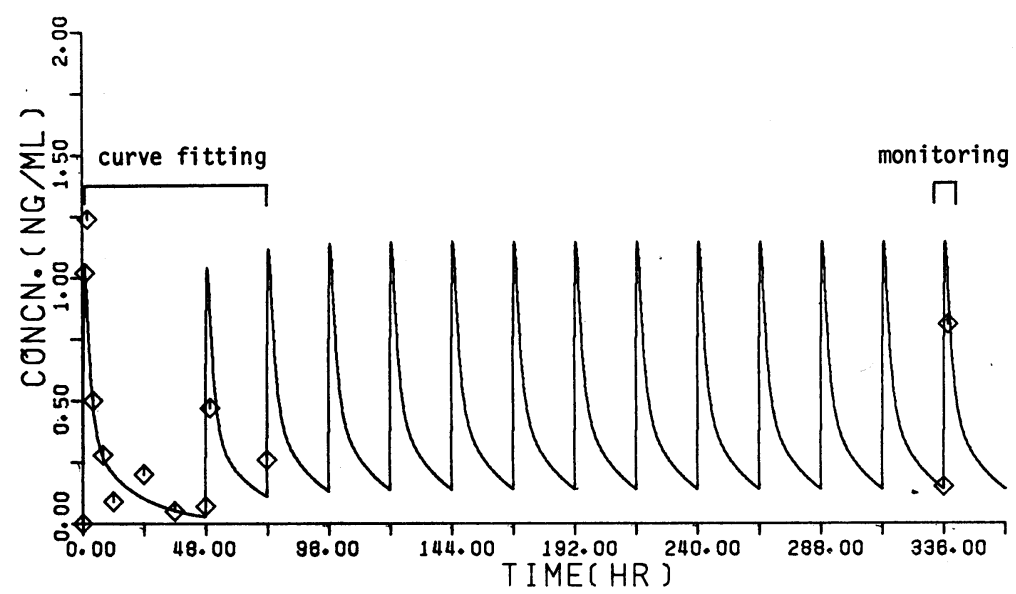

Fig. 5. Predicted and Observed Serum Digoxin Concentrations in Patient $\mathrm{C}$

$\diamond$ : Observed concentrations

- Predicted concentration curve

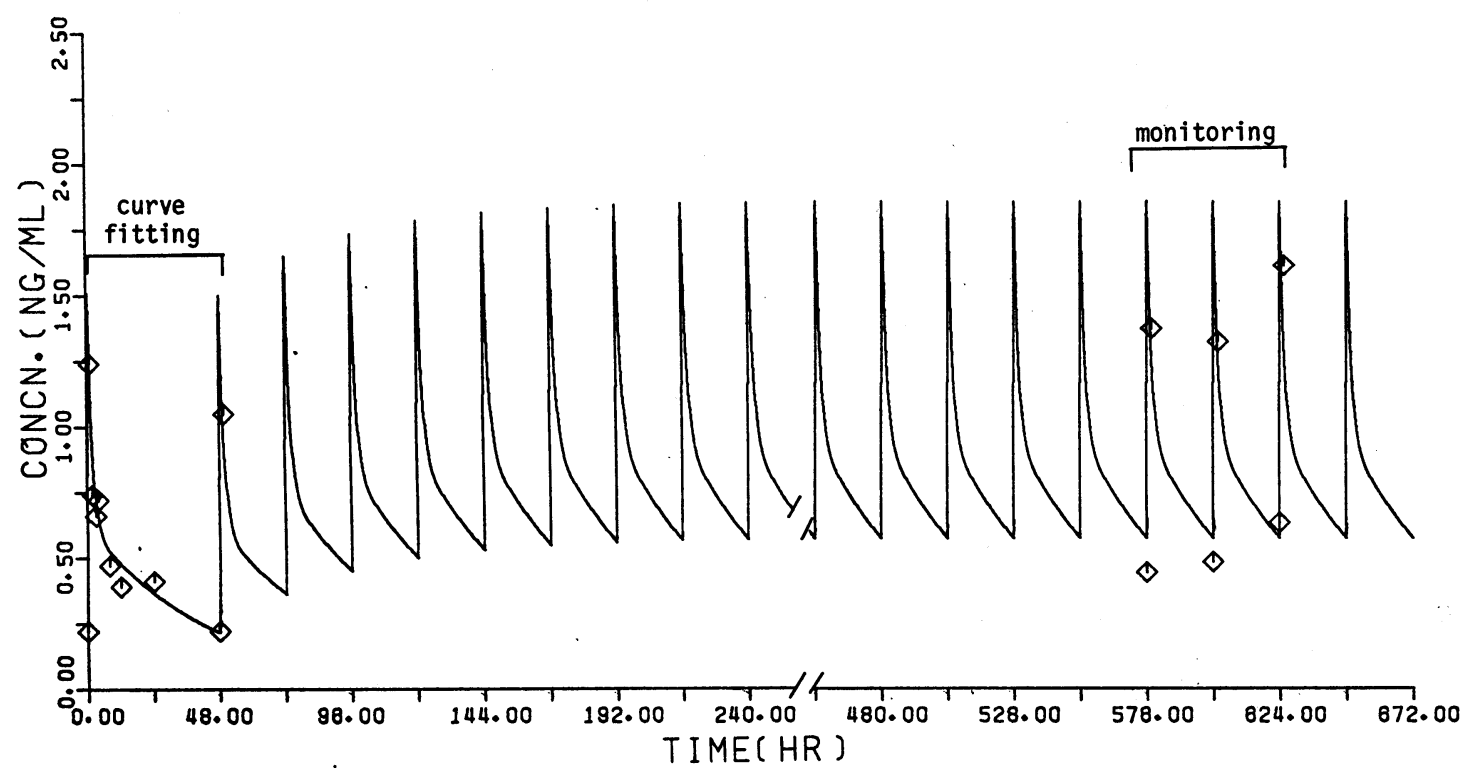

Fig. 6. Predicted and Observed Serum Digoxin Concentrations in Patient D

$\diamond$ : Observed concentrations

- : Predicted concentration curve

タリング値と極めてよい一致を示した.

4) 症例-4 (Fig. 8, 患者F)

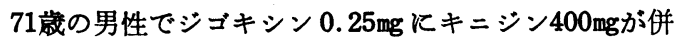
用されていた，このときパラメータ算出を行ったが，ジ ゴキシンの血中濃度が高く, 副作用発現が心配されたた め, キニジンを休薬, 同時にジゴキシンも $0.125 \mathrm{mg}$ に減 量した。 その後ジゴキシン単独投与の条件下で再びパラ メータの算出を行った (Table 3). こうして得られたジ
ゴキシン単独投与時及びキニジン併用時のパラメータを 用い，それぞれについて 1 日0.25mg投与での血中濃度シ ミュレーションを行ったところ, Fig. 8 に示す結果が得 られた。この図からジゴキシンの血中濃度がキニジン併 用時に約 2 倍高くなることが予測される.

\section{3. 血中浀度の予測性}

以上の結果をモニタリング実測值とこれに対応する予 測値との間にはよい相関が認められ (Fig. 9), 予測誤差 


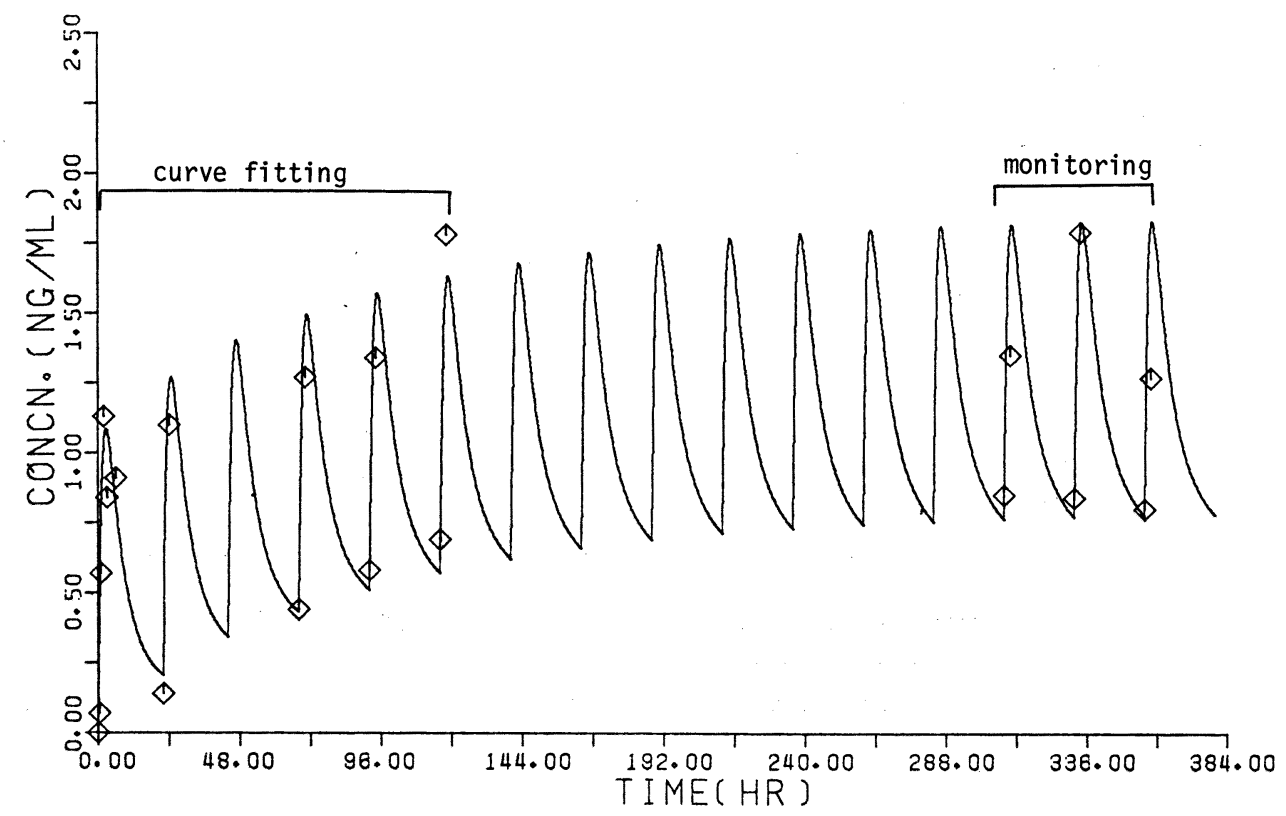

Fig. 7. Predicted and Observed Serum Digoxin Concentrations in Patient E $\diamond$ : Observed concentrations

— : Predicted concentration curve

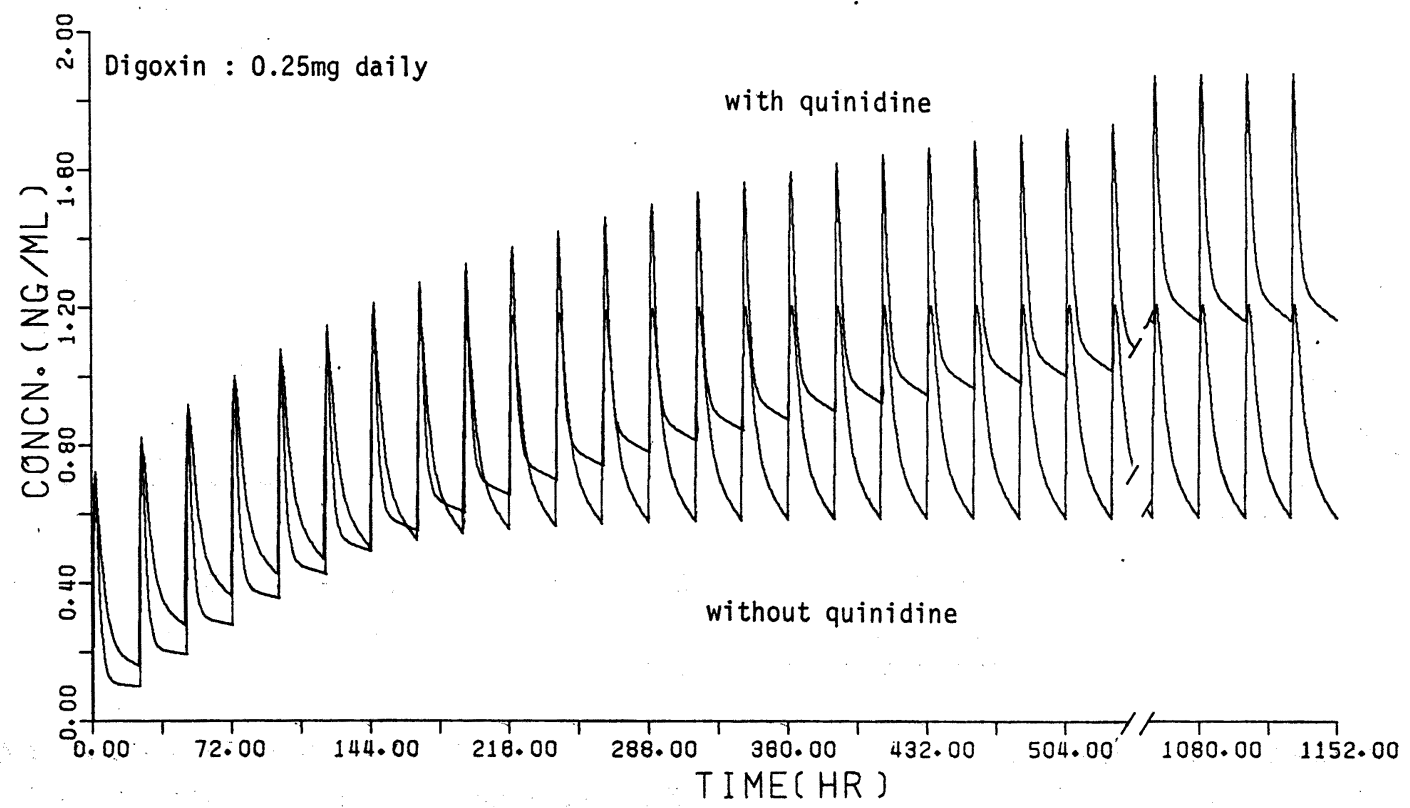

Fig. 8. Simulated Serum Digoxin Concentrations with and without Quinidine Administration in Patient $\mathrm{F}$

$\{$ 予測值一実測值| $/$ 予測值 $\} \times 100 \%$ で表わすとすれ

ば, 実測值全データの平均で $11.9 \pm 9.4(\% \pm$ S.D., $\mathrm{n}=$ 20), そのうち最低血中濃度で $9.6 \pm 7.4(n=11)$, および 最高血中濃度で $14.7 \pm 11.1(n=9)$ であった.
コンピュータの補助を必要としないノモグラムや比較 的簡単な数式については, 最もよい予測性を与える方法

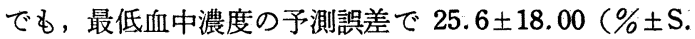
D., $\mathrm{n}=40$ ) であるとされている.4)このことから, 例数 
Table 3. Pharmcokinetic Parameters of Digoxin Estimated from Repetitive Dosing Data

\begin{tabular}{|c|c|c|c|c|c|c|c|c|c|}
\hline Patient & $\begin{array}{r}\left.\operatorname{Sex}^{a}\right) \\
(\end{array}$ & $\begin{array}{c}\text { Age } \\
\text { (years) }\end{array}$ & $\begin{array}{c}\text { Weight } \\
(\mathrm{kg})\end{array}$ & Diagnosis & $\begin{array}{c}\text { Daily Dose } \\
\text { (mg) }\end{array}$ & $\begin{array}{c}k_{a} \\
\left(h^{-1}\right)\end{array}$ & $\begin{array}{c}\alpha \\
\left(h^{-1}\right)\end{array}$ & $\begin{array}{c}\beta \\
\left(h^{-1}\right)\end{array}$ & $\begin{array}{l}v_{\beta}^{b)} \\
(1)\end{array}$ \\
\hline C & $\mathrm{F}$ & 80 & 44.0 & dextrocardia & 0.25 & 2.02 & 0.520 & 0.0545 & 514 \\
\hline$D$ & M & 36 & 48.0 & $\begin{array}{l}\text { congestive heart } \\
\text { failure }\end{array}$ & 0.25 & 9.64 & 0.700 & 0.0222 & 573 \\
\hline$E$ & $M$ & 36 & 62.5 & $\begin{array}{l}\text { congestive heart } \\
\text { failure }\end{array}$ & 0.25 & 0.740 & 0.181 & 0.0101 & 864 \\
\hline $\mathrm{F}$ & $M$ & 71 & 62.0 & angina pectoris & {$\left[\begin{array}{l}0.125 \\
0.25\end{array}\right.$} & 0.748 & 0.241 & $\begin{array}{l}0.0169 \\
0.00376\end{array}$ & 772 \\
\hline
\end{tabular}

a) $M$ : male, $F$ : female.

b) Assuming that absorption rate constant equals 1.0 .

c) With quinidine.

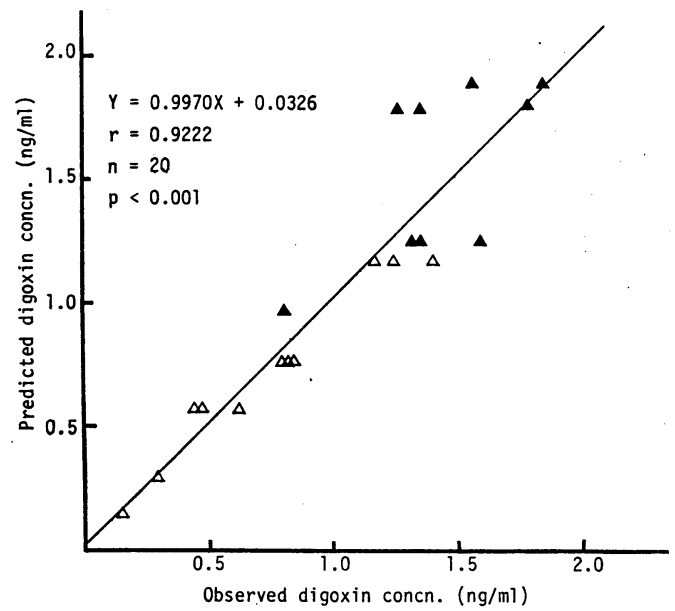

Fig. 9. Correlation between Observed and Predicted Serum Digoxin Concentrations

$\triangle:$ Minimum digoxin concentrations at steady state

A : Maximum digoxin concentrations at steady state

は少ないながら本法による最低血中濃度の予測誤差 9.6 \pm 7.4 といら值は，本法の有用性を示するのと考えられ る.

おわりに

単回投与の血中濃度データに, 繰り返し投与時の血中
データを加えてパラメータを算出し，このパラメータを 用いて血中濃度の予測を行ったところ，よい予測值が得 られた。 このことは本法の有用性を示するのと考えら れ，本法による投与計画立案は臨床治療上有意義と思わ れる。

謝辞 DIGOXIN RIABEAD キットを提供していただ いたダイナボット RI 研究所に深謝いたします.

\section{文献}

1）斉藤秀哉, 首藤 勇: “臨床医のためのジギタリ スの使い方一臨床薬理学に基つくく最新の治療法 一," 新興医学出版社, 東京, 1975 .

2）花野 学, 藤田 浩, 粟津荘司 編著: “薬の体内 動態一ファーマコキネティクスの実際, ”講談社サ イェンティフィク，東京, 1981 , p. 111 142.

3） 中村 要, 近野教昭: “薬物治療適正化のための 薬物血中濃度测定の実際,"”田村善蔵, 堀岡正義 編, 薬業時報社, 東京, 1981, p. $219 \sim 228$.

4) G. Tsujimoto, T. Sasaki, T. Ishizaki, T. Suganuma, and $\mathrm{H}$. Hirayama : Br. J. Clin. Pharmac., 13, 493 (1982).

5) 大和田栄治, 伊藤圭二, 新岡正法, 荒川昌子, 福 田良平：臨床成人病, 12, 1509 (1982).

6) 西花正樹, 布施昌孝, 岡崎正子, 福嶋邫行, 夏井 坂徹, 中島茂夫, 鈴木 明, 斉藤晶子, 大和田栄 治, 伊藤圭二: 病院薬学 (投稿中). 